\title{
Preliminary Investigation of Inorganic and Organic Contaminants in Soils within Wukari Metropolis, Taraba State, Nigeria
}

\author{
G.G. Yebpella ${ }^{1, *}$, B.N. Hikon ${ }^{1}$, A.M. Magomya ${ }^{1}$, M. Paninga ${ }^{1}$ \\ ${ }^{1}$ Department of Chemical Sciences, Federal University Wukari, P.M.B 1020 Wukari, North East Nigeria. \\ ${ }^{*}$ Corresponding author Ph: +2348038504042 ; Email: mails4gary1@yahoo.com \\ DOI: https://doi.org/10.34256/irjmt2149 \\ Received: 17-06-2021, Revised: 06-07-2021, Accepted: 08-07-2021, Published: 09-07-2021
}

Abstract: This study aimed at the preliminary investigation of inorganic and organic contaminants in soils within Wukari metropolis and to assess the contamination status and metal bioavailability. Digested soil samples for total metals and fractionation were analyzed for heavy metal concentrations in triplicates using Flame Atomic Absorption Spectrophotometer while 5 Varian Bond Elu SI SPE cartridges was used for solid phase extraction and the soil sample extracts were analyzed by GC-MS. The percentage bioavailability of metals ranged from Fe: $13.81-98.85$ \%, Ni: $65.01-80.93 \%$, Cr: $34.82-77.19 \%$, Pb: $66.93-86.59 \%$ and Co: $70.35-99.14 \%$ respectively. The bioavailability of $\mathrm{Fe}, \mathrm{Ni}, \mathrm{Pb}$ and $\mathrm{Co}$ station ST3 which is an agricultural area were above $50.00 \%$. This indicates that food crops grown in the area may be contaminated by the metals. Irrespective of sampling points, the distribution of metals in the soil samples generally followed the order Fe: residual > carbonate > exchangeable > oxidizable; Ni: exchangeable > carbonate $>$ oxidizable $>$ residual; $\mathrm{Pb}$ : exchangeable $>$ residual $>$ carbonate $>$ oxidizable; Co: exchangeable > carbonate $>$ oxidizable > residual. Organic contaminants such as Halo alkanes; bromodichloromethane (molecular weight $162.0 \mathrm{~g} / \mathrm{mol}$ ) and chloroform (molecular weight $118.0 \mathrm{~g} / \mathrm{mol}$ ) were detected in ST1 while, 1, 1, 2 trichloroethane (molecular weight $132.0 \mathrm{~g} / \mathrm{mol}$ ). Another contaminant phenol d5 was recorded in sample ST2, ST3 and ST4 respectively. BTEX compounds were also contaminants present in ST5 (Fuel station near some automobile workshops).

Keywords: Soil, Bioavailability, Heavy Metals, Organic, Contaminants, Speciation

\section{Introduction}

Soil is a mixture of broken rocks and minerals, living organisms, and decaying organic matter called humus. Soil is an important component of the natural environment but can become contaminated by introduction and accumulation of organic compounds, heavy metals and metalloids through emissions from the rapidly expanding industrial areas, mine tailings, disposal of high metal wastes, leaded gasoline and paints, land application of fertilizers, animal manures, sewage sludge, pesticides, wastewater irrigation, coal combustion residues, spillage of petrochemicals, and atmospheric deposition [1]. Humans are at risk from contaminated soils through dermal contact, ingestion, consumption of food grown on contaminated areas and inhalation of dusts or vapors [2]. Soils may fail to support vegetation because of phytotoxic effects of contaminants or disrupted biological cycling of nutrients [3]. The combustion of fuels hydrocarbons are the contaminants of soils and aquifers [4]. Benzene, toluene, ethylbenzene and xylenes (BTEX) are volatile organic components of petroleum and its derivatives, such as gasoline and diesel fuel and phenolic compounds [5]. The soil eventually becomes a repository of hazardous organic compounds and heavy metals released from automobile workshops activities. Heavy metals are considered to be one of the major sources of contaminants in soil, because of their significant effect on the ecological quality [6]. The contaminant-soil interaction is mainly occurred by sorption, complexation and precipitation [7].

This work aimed at the preliminary investigation of inorganic and organic contaminants in soils within Wukari metropolis and to establish the presence of such contaminants in soils from automobile workshops, meat singed areas, farmland and gasoline stations. Hence assess their contamination status.

\section{Materials and Methods}

\subsection{Study Area}

Taraba State is located in north eastern part of Nigeria. Wukari is the headquarters of Wukari Local 
Government Area of Taraba State. It is located between latitude $7^{\circ} 51^{\prime} \mathrm{N}$ to $7^{\circ} 85^{\prime} \mathrm{N}$ and longitude $9^{\circ} 46^{\prime} \mathrm{E}$ to $9^{\circ} 78^{\prime} E$ of the Greenwich meridian. Wukari Local Government area is situated in the southern part of Taraba State and it is about two hundred kilometers away from Jalingo the state capital. The Local Government is bounded by Plateau State in the North, Benue State in the Southwest. It has an area of about $4308 \mathrm{~km}^{2}$ (1663 sq mi).

\subsection{Sample Collection and Preparation}

Soil samples were collected from selected occupational areas within Wukari town during wet season, $13^{\text {th }}$ January, 2021. About five sample stations were mapped out and were designated as ST1: Automobile workshops (new site), ST2: Automobile workshops (new market), ST3: Agricultural Farmlands around new site, ST4: Areas where meats are singed with scrap tyres and plastic wastes and ST5: NNPC filling station and its environs. Each of the stations were further divided into four substations which are 50 meters apart.

A $250.0 \mathrm{~g}$ each of the samples were collected randomly from four substations of ST1 given a total of 1 $\mathrm{kg}$ soil samples. This was done with the aid of a stainless-steel hand trowel at the depth of $0-15 \mathrm{~cm}$ and stored in a clean polythene bag that was previously washed by soaking in $1 \% \mathrm{HCl}$. The soil samples from each substation were bulked together to form a representative sample for ST1. The sample was airdried in the laboratory for two days, manually sorting out plant and animals debris. The sample was then powdered to fine sizes using agate mortar and pestle and thoroughly mixed to achieve homogeneity. The powdered sample was then sieved mechanically to obtain a fraction that is less than $63.00 \mu \mathrm{m}$. The soil sample was stored in plastic containers at room temperature until ready for further analysis. This procedure was repeated for station ST2, ST3, ST4 and ST5 respectively.

\subsection{Measurement of Soil pH}

Soil water mixture was prepared in a ratio 1:2. A $10.00 \mathrm{~g}$ of soil sample was weighed into a $20 \mathrm{~mL}$ of distilled water followed by occasional shaking for 10 mins and allowed to stand for a period enough to release the hydrogen ion. The $\mathrm{pH}$ was then measured and recorded in triplicates using $\mathrm{HI} 8014 \mathrm{pH}$ meter (Hanna instruments).

\subsection{Aqua-regia Extraction Method for Total Metals}

Aqua-regia method for total metal extraction as described in METHOD 3050B of the United State Environmental Protection Agency for acid digestion of sediments, sludge and soils [8], was adopted. The digested soil samples was analyzed for heavy metals in triplicates using Flame Atomic Absorption Spectrophotometer, AAS instrument (Buck Scientific AAS model 210VP).

\subsection{BCR Method}

Optimized BCR procedures were used for the sequential extraction of metal fractions from soil as described by [9]. This method separate the metals into four fractions notably: acid extractable, reducible, oxidisable and residual fractions. The digested fractions of soil samples were analyzed for heavy metals in triplicates using Flame Atomic Absorption Spectrophotometer, AAS instrument (Buck Scientific AAS model 210VP).

The result of fractions obtained from the speciation analysis was used to calculate percentage bioavailability of the heavy metals in the studied areas.

$$
\begin{gathered}
\% \text { Bioavailability }= \\
\frac{\text { exchangeable }+ \text { reducible }+ \text { oxidizable }}{\text { exchangeable }+ \text { reducible }+ \text { oxidizable }+ \text { residual }} \times 100
\end{gathered}
$$

\subsection{Solid Phase Extraction Method}

The extraction of Halo Alkanes and BTEX from the soil was carried out by solid phase extraction using USEPA method. This was carried out by shaking $20 \mathrm{~mL}$ of acetone together with $10.00 \mathrm{~g}$ soil sample for $30 \mathrm{~min}$ in a SPE cartridge. The mixture was separated by centrifuging at $1000 \mathrm{rpm}$ for $5 \mathrm{~min}$. A $10 \mathrm{~mL}$ acetone and $5 \mathrm{~mL}$ of 2-propanol was added to the supernatant. A $15 \mathrm{~mL}$ of sample solution was eluted into glass vials by the addition of $2 \times 1.5 \mathrm{~mL}$ of tetrahydrofuran to the SPE columns. The resulting extract was analyzed by GC-MS (HP Agilent 6890N GC gas chromatograph$5973 \mathrm{~N}$ mass spectrometer, Santa Clara, CA) according to [10].

\subsection{Quality Assurance}

In order to check the reliability of the analytical procedure employed for heavy metals determination, a certified reference material of similar composition to the unknown samples was digested and analyzed in like manner to the samples and replicate analysis of samples together with blank were carried out.

\subsection{Data Analysis}

Data was subjected to statistical analysis for standard deviation and histogram chart to assess the relationship between the various metal fractions. 


\section{Result and Discussion}

The measured values and the certified values for six (6) heavy metals were presented in table 1 . The result showed high value of $\mathrm{Pb}$ which is above the certified value. $\mathrm{Fe}, \mathrm{Cr}$ and $\mathrm{Co}$ showed least values compared to the reference values. Heavy metals, $\mathrm{Ni}$ extracted from the soil was satisfactory as it is within the reference value.

The result of the soil pH obtained from ST1 to ST2 ranges from 6.400 to 7.900 as shown in table 2 . This showed that sample in ST1 was slightly acidic, ST2 and ST3 are very slightly acidic, ST4 and ST5 are slightly alkaline. In acidic soils, the mobility and availability of metallic elements is much higher than in soils with neutral and alkaline $\mathrm{pH}$ [11]. The effect of $\mathrm{pH}$ on the availability of metallic elements in the soil has been observed to vary with the content and type of organic matter [12, 13].

The mean of total metal concentrations of heavy metals in soil were reported in table 3 . The concentration of iron ranged from 53.99 to $70.48 \mathrm{mg} / \mathrm{kg}$ across all sample stations. The highest concentration of iron was observed in ST1 with the least in ST2. The highest concentration of nickel was recorded in ST2 with value $46.45 \mathrm{mg} / \mathrm{kg}$. The concentration of lead ranged from 109.2 to $897.9 \mathrm{mg} / \mathrm{kg}$ across sample stations. The mean value of $\mathrm{Pb}$ recorded in this study was, however, lower than the mean value of 2,645.31 $\mathrm{mg} / \mathrm{kg}$ reported by [14] in waste dump soil. The high level of lead in ST1 and ST2 were 753.0 and 897.9 $\mathrm{mg} / \mathrm{kg}$ respectively. The values of lead observed in this study were by far more than those reported by [15], which ranged from 1.280 to $184.4 \mathrm{mg} / \mathrm{kg}$ in soil samples collected from Korle Lagoon area in Accra, Ghana. The high level of lead in ST1 and ST2 could be attributed to anthropogenic activities such as panel beating, fumes from vehicles, automobile repairs and electrical waste discharge.

Cobalt has the least concentration among all the studied metals. The highest concentration was observed in ST2 and ST4 $(0.516 ; 0.371 \mathrm{mg} / \mathrm{kg})$. The low level of cobalt in ST3 was as a result of agricultural activities carried out in the area which has little or no influence in the release of heavy metals unto the soil. The mean concentration of $\mathrm{Ni}$ recorded at the various stations were below the [16] permissible limit of 50.00 $\mathrm{mg} / \mathrm{kg}$. Chromium concentration, $63.40 \mathrm{mg} / \mathrm{kg}$ in ST3 was found to be the highest in this study and higher than $56.00 \mathrm{mg} / \mathrm{kg}$ reported by [15]. The high concentration of chromium could be as a result of electronics waste such as refrigerator, used computers, cables, printers, photocopy machines, automobile tires and batteries close to the station.

Table 1. Analysis of reference material (SOIL BCR-140) compared to reference value

\begin{tabular}{|c|c|c|c|c|c|}
\hline Elements (mg/kg) & $\mathrm{Fe}$ & $\mathrm{Ni}$ & $\mathrm{Cr}$ & $\mathrm{Pb}$ & $\mathrm{Co}$ \\
\hline A. Values & 60.85 & 36.17 & 34.20 & 441.7 & 0.291 \\
\hline R. Values & 22000 & 31.90 & 89.60 & 17.28 & 9.660 \\
\hline \multicolumn{7}{|l}{ Value = Analyzed value, R. Value $=$ Reference value. } \\
\hline
\end{tabular}

Table 2. Result of soil pH.

\begin{tabular}{|c|c|c|c|c|c|}
\hline Samples & ST1 & ST2 & ST3 & ST4 & ST5 \\
\hline $\mathrm{pH}$ & 6.400 & 6.700 & 6.900 & 7.600 & 7.900 \\
\hline
\end{tabular}

Table 3. Total concentrations of heavy metals in soils $(\mathrm{mg} / \mathrm{kg})$.

\begin{tabular}{|c|c|c|c|c|c|}
\hline Stations & $\mathrm{Fe}$ & $\mathrm{Ni}$ & $\mathrm{Cr}$ & $\mathrm{Pb}$ & $\mathrm{Co}$ \\
\hline ST1 & $70.48 \pm 0.095$ & $35.30 \pm 0.265$ & $26.85 \pm 0.04$ & $753.0 \pm 0.185$ & $0.207 \pm 0.001$ \\
\hline ST2 & $53.99 \pm 0.055$ & $46.45 \pm 0.125$ & $26.30 \pm 0.075$ & $897.9 \pm 0.190$ & $0.516 \pm 0.005$ \\
\hline ST3 & $58.56 \pm 0.075$ & $32.75 \pm 0.125$ & $63.40 \pm 0.065$ & $109.2 \pm 0.10$ & $0.116 \pm 0.003$ \\
\hline ST4 & $61.19 \pm 0.085$ & $45.45 \pm 0,030$ & $20.75 \pm 0.015$ & $331.1 \pm 0.05$ & $0.371 \pm 0.005$ \\
\hline ST5 & $60.05 \pm 0.065$ & $20.90 \pm 0.10$ & $33.80 \pm 0.090$ & $117.1 \pm 0.64$ & $0.245 \pm 0.002$ \\
\hline Mean & $60.85 \pm 3.045$ & $36.17 \pm 1.015$ & $34.20 \pm 1.421$ & $441.7 \pm 2.821$ & $0.291 \pm 0.012$ \\
\hline
\end{tabular}


The result of percentage bioavailability was represented in table 4 below. The ease of extraction is related to the degree of solubility and bioavailability of metal form. The value of bioavailability for metals provides information about their potential mobility in soils and availability to plants [17]. The value less than $50.00 \%$ for any element indicates that the element is immobile and unavailable for plants. However, the value of bioavailability up to $50.00 \%$ or greater than $50.00 \%$ for a particular metal suggests that the element is highly mobile and available for plants [18, 19].

The result recorded from the studied areas showed that nickel, chromium, lead and cobalt are bioavailable in ST1, ST2, ST4 and ST5. However, the bioavailability of iron in ST1 and ST5 were less than $50.00 \%$. The non-bioavailability is a symptom of moderate stability of the above metals in the samples. This could be linked to the high organic matter and residual content in the soils which can lead to the formation of insoluble complex compounds which may be limiting the mobility of heavy metals [20]. The bioavailability of $\mathrm{Fe}, \mathrm{Ni}, \mathrm{Pb}$ and $\mathrm{Co}$ in sample station ST3 which is an agricultural area was above $50.00 \%$.
This indicates that food crops grown in the area may be contaminated by the metals. The percentage bioavailable chromium in ST3 is less than $50.00 \%$ meaning it cannot be found in food crops grown there. However, iron, lead, nickel and cobalt may be present on food crops grown in ST3 since their percentage bioavailability are more than $50.00 \%$.

The percentage bioavailability of iron nickel, chromium, lead and cobalt ranged from metals studied ranged from 13.81 - $98.85 \%, 65.08$ - $80.93 \%, 34.82$ $77.19 \%, 66.93$ - $86.59 \%$ and 70.35 - $99.14 \%$ respectively.

The concentration of nickel and cobalt obtained in this work are high in the exchangeable and carbonate fractions than residual fraction (figure 1). The exchangeable and carbonate fraction of any metal ion are the most readily available for uptake by living organisms, hence these metals are the most bioavailable with percentage bioavailability of 80.93 and $99.14 \%$ respectively. Based on the $\mathrm{pH}$ result obtained, the high released of metals is in agreement with the report of [21] that metal release rates were affected to a much greater extent in the low $\mathrm{pH}$ (4-7) condition than in high $\mathrm{pH}(8-10)$ condition.

Table 4. Percentage bioavailability of heavy metals in soil (\%).

\begin{tabular}{|l|l|l|l|l|l|}
\hline Metal & $\mathrm{Fe}$ & $\mathrm{Ni}$ & $\mathrm{Cr}$ & $\mathrm{Pb}$ & Co \\
\hline ST1 & 31.14 & 80.93 & 76.25 & 81.29 & 95.17 \\
\hline ST2 & 91.17 & 76.57 & 77.19 & 86.59 & 70.35 \\
\hline ST3 & 81.92 & 77.63 & 34.82 & 78.34 & 99.14 \\
\hline ST4 & 98.85 & 78.21 & 76.95 & 83.34 & 75.20 \\
\hline ST5 & 13.81 & 65.06 & 61.45 & 66.93 & 78.37 \\
\hline
\end{tabular}

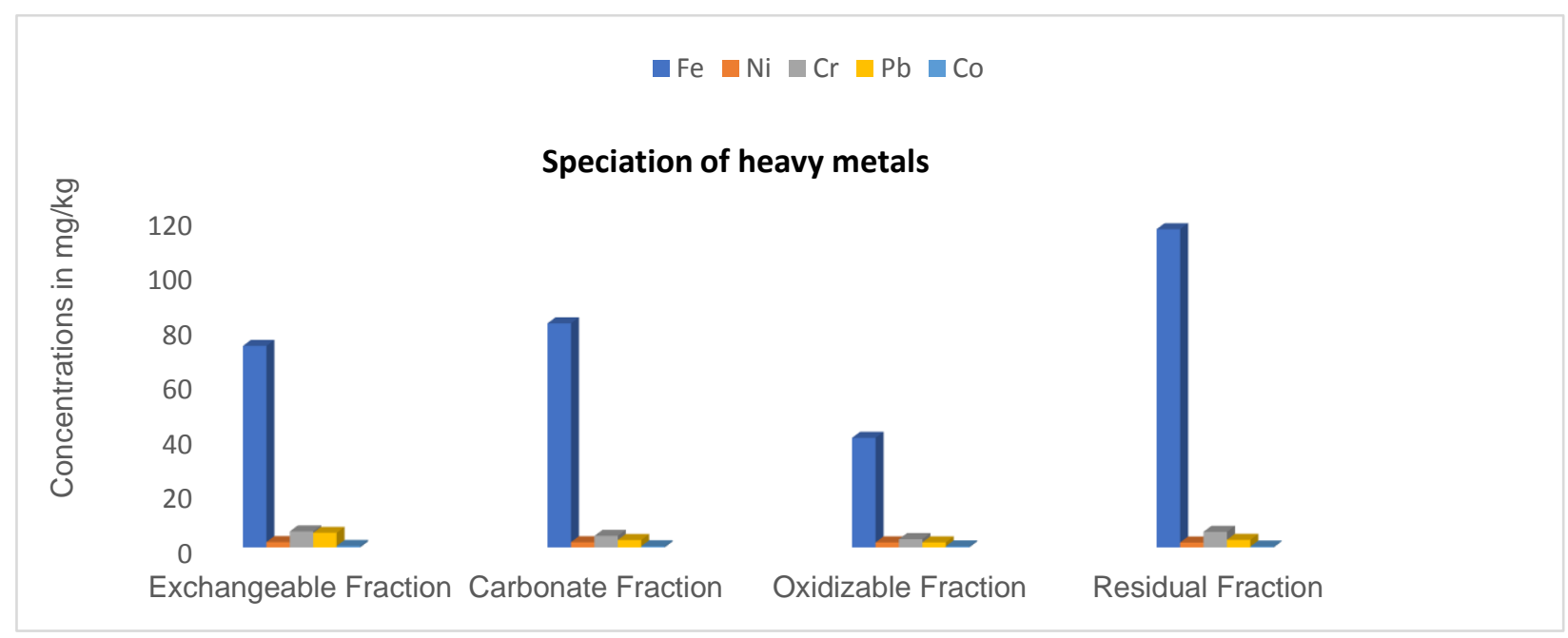

Figure 1. Speciation of metals across sample locations. 
Similar observation was made for lead and chromium (figure 1). From figure 1, the results showed high concentration in the exchangeable fraction for lead and chromium irrespective of sample stations. The relatively high concentration of lead and chromium ions in the exchangeable fraction of the soil sample may be attributed to a favorable $\mathrm{pH}$ value which encourages desorption of the metals from the soils [22]. The presence of lead and chromium in significant concentrations in the exchangeable and carbonate fractions may pose a serious health threats affecting human health and wellbeing since toxic metals are readily available for uptake by living organisms [23]. The result of chromium in the exchangeable and oxidizable fractions was supported by [24], it is rather uncommon to relate $\mathrm{Cr}$ with the oxidizable fraction.

Irrespective of sampling stations, the distribution of metals fractions in the soil samples generally followed the order below for the various metal studied. oxidizable

Fe: residual $>$ carbonate $>$ exchangeable $>$ residual

Ni: exchangeable $>$ carbonate $>$ oxidizable $>$ oxidizable

Cr: exchangeable $>$ residual $>$ carbonate $>$ oxidizable

$\mathrm{Pb}$ : exchangeable $>$ residual $>$ carbonate $>$

Co: exchangeable $>$ carbonate $>$ oxidizable $>$ residual

The concentrations of nickel, chromium, lead and cobalt was high in the exchangeable fractions while iron has high concentration in the residual fraction, followed by chromium and lead. The amount of $\mathrm{Fe}$ in the residual fractions was recorded as 116.0 $\mathrm{mg} / \mathrm{kg}$ as showed in figure 1 above. This high values is in agreement with the finding of [25]. Because of this, Fe can be considered as partially mobile or immobile and bioavailable for plant uptake. This implies that, the metals is strongly bound to minerals and resistant components, and do not represent environmental risk. The organic fraction is not very mobile or readily available, since it is associated with high molecular weight stable humic substances in the sediments which could release only small quantity of these metals in a slow manner without significant environmental implications [26]. Almost all the metals has low concentrations in the oxidizable fractions.

The same sample ST1, ST2, ST3, ST4 and ST5 were subjected for gas chromatography analysis with electron ionization detector (EID) via solid phase extraction method. The concentrations of compounds expected in the samples appeared to be well below the detection limits of the instruments used in this work. Other instruments tried could not give reasonable result. A special GC column was used to separate the compounds. The GC chromatograms were zoomed out in order to reveal the peaks, hence the distorted baseline. Before zooming, only peaks due to the solvents could be seen (retention time and area of peaks). Possible compounds and the mass spectra of the most closely related compounds as identified by the database. However, the names of the possible compounds and their molecular weights are presented in table 4 below.

The names of possible organic contaminants in ST5 and their formula and molecular weight are presented in table 5. These include Carbon tetrachloride $\left(\mathrm{CCl}_{4}\right)$, 4-Chloro-3-methyl phenol $\left(\mathrm{C}_{7} \mathrm{H}_{7} \mathrm{ClO}\right)$, 2-methyl phenol $\left(\mathrm{C}_{7} \mathrm{H}_{8} \mathrm{O}\right)$ Ethyl benzene $\left(\mathrm{C}_{6} \mathrm{H}_{5} \mathrm{CH}_{2} \mathrm{CH}_{3}\right)$, Tert. butyl benzene Toluene $\left(\mathrm{C}_{7} \mathrm{H}_{8}\right)$, 4Isopropyl toluene $\left(\mathrm{C}_{10} \mathrm{H}_{14}\right)$, and Xylene $\left(\mathrm{C}_{8} \mathrm{H}_{10}\right)$ with molecular weight $152 \mathrm{~g} / \mathrm{mol}, 142 \mathrm{~g} / \mathrm{mol}, 108.0 . \mathrm{g} / \mathrm{mol}$, $106.0 \mathrm{~g} / \mathrm{mol}, 134.0 \mathrm{~g} / \mathrm{mol}, 92.00 \mathrm{~g} / \mathrm{mol}, 134.00 \mathrm{~g} / \mathrm{mol}$ and $106.0 \mathrm{~g} / \mathrm{mol}$ respectively while those of ST4 includes Phenol d5 $\left(\mathrm{C}_{6} \mathrm{H}_{6} \mathrm{O}\right)$, bromodichloromethane $\left(\mathrm{CHBrCl}_{2}\right)$, 1, 1, 2 trichloroethane $\left(\mathrm{C}_{2} \mathrm{H}_{3} \mathrm{Cl}_{3}\right)$, and Chloroform $\left(\mathrm{CHCl}_{3}\right)$ with molecular weight $99.00 \mathrm{~g} / \mathrm{mol}$, $162.0 \mathrm{~g} / \mathrm{mol}, 132.0 \mathrm{~g} / \mathrm{mol}$ and $118.0 \mathrm{~g} / \mathrm{mol}$ respectively. From the results, the major organic contaminants comprised of halo alkanes, phenols, and BTEX (Benzene, Toluene, Ethyl benzene, and Xylene), as presented in table 4. Halo alkanes are a group of alkanes substituted with halogens. They are found in the environment from different products such as flame retardants, solvents, oils, etc.

Bromodichloromethane, chloroform, 1, 1, 2 trichloroethane, and carbon tetrachloride are a few halo alkanes identified in this work. The stations for which these contaminants were found include samples ST1 and ST4. Bromodichloromethane (molecular weight $162.0 \mathrm{~g} / \mathrm{mol}$ ) and chloroform (molecular weight 118.0 $\mathrm{g} / \mathrm{mol}$ ) were detected in ST1 while, 1, 1, 2 trichloroethane (molecular weight $132.0 \mathrm{~g} / \mathrm{mol}$ ), bromodichloromethane and chloroform were found in ST4. These are automobile workshops and areas where meat are singed with tyre and plastics materials. [27], found that total PAHs and BTEX concentrations of soil samples from automobile mechanic workshops ranged from $0.601-3.678 \mathrm{mg} / \mathrm{kg}$ and $<0.001-0.013$ respectively. Soil sample collected from an industrial area of the metropolis had a highest concentration of $3.678 \mathrm{mg} / \mathrm{kg}$ PAHs and $0.003 \mathrm{mg} / \mathrm{kg} \mathrm{BTEX}$. 
Table 5. Results of organic contaminants analyzed by GC-MS

\begin{tabular}{|l|l|l|l|l|l|}
\hline $\begin{array}{l}\text { Sample } \\
\text { Stations }\end{array}$ & Compounds & Formula & Mwt & $\begin{array}{l}\text { Peak } \\
\text { Area }\end{array}$ & $\begin{array}{c}\text { Retention time } \\
\text { (min) }\end{array}$ \\
\hline ST1 & Bromodichloromethane & $\mathrm{CHBrCl}_{2}$ & 162.0 & 8460 & 4.869 \\
\hline & Chloroform & $\mathrm{CHCl}_{3}$ & 118.0 & 4363 & 5.103 \\
\hline ST2 & Phenol d5 & $\mathrm{C}_{6} \mathrm{H}_{6} \mathrm{O}$ & 99.00 & 3988 & 4.209 \\
\hline ST3 & Phenol d5 & $\mathrm{C}_{6} \mathrm{H}_{6} \mathrm{O}$ & 99.00 & 4192 & 6.398 \\
\hline ST4 & Phenol d5 & $\mathrm{C}_{6} \mathrm{H}_{6} \mathrm{O}$ & 99.00 & 5674 & 4.715 \\
\hline & Bromodichloromethane & $\mathrm{CHBrCl}_{2}$ & 162.0 & 4660 & 4.938 \\
\hline & $1,1,2$ trichloroethane & $\mathrm{C}_{2} \mathrm{H}_{3} \mathrm{Cl}_{3}$ & 132.0 & 13095 & 5.179 \\
\hline & Chloroform & $\mathrm{CHCl}_{3}$ & 118.0 & 15649 & 5.400 \\
\hline ST5 & $4-$ Chloro-3-methyl phenol & $\mathrm{C}_{7} \mathrm{H}_{7} \mathrm{ClO}$ & 142.0 & 2741 & 4.291 \\
\hline & $2-$ methyl phenol & $\mathrm{C}_{7} \mathrm{H}_{8} \mathrm{O}$ & 108.0 & 4027 & 5.164 \\
\hline & Ethyl benzene & $\mathrm{C}_{6} \mathrm{H}_{5} \mathrm{CH}_{2} \mathrm{CH}_{3}$ & 106.0 & 2456 & 5.306 \\
\hline & Tert. butyl benzene & $\mathrm{C}_{10} \mathrm{H}_{14}$ & 134.0 & 2945 & 5.394 \\
\hline & Toluene & $\mathrm{C}_{7} \mathrm{H}_{8}$ & 92.00 & 3378 & 5.458 \\
\hline & $4-$ Isopropyl toluene & $\mathrm{C}_{10} \mathrm{H}_{14}$ & 134.0 & 4804 & 6.038 \\
\hline & Xylene & $\mathrm{C}_{8} \mathrm{H}_{10}$ & 106.0 & 12883 & 6.275 \\
\hline
\end{tabular}

The Agency for toxic substances and disease registry (ATSDR) identified Bromodichloromethane as an irritating compound and probably carcinogenic [28].Although Chloroform has good anaesthetic, industrial and laboratory uses, it is toxic and can cause damage such as organ damage, heartbeat irregularities and cancer [29].

The compound, 1,1,2 trichloroethane depresses the central nervous system on inhalation and may cause dizziness, headache, nausea or cancer while carbon tetrachloride (a solvent used in the production of hydrofluorocarbons) is primarily known for causative effects on the liver, kidney and central nervous system [30].

Phenols are primarily used for the production of phenolic resins which are used in the plywood, automotive and appliance industries. They are also used as disinfectants, herbicides, pesticides etc. And this explains their existence in ST3 which is an agricultural area (farmland). Once evaporated from products, they contaminate the air and humans can be exposed to them and also be at health risk by breathing contaminated air [31]. The presence of phenol in ST1, ST2 and ST3 could be attributed to the panel beating, welding, painting and automobile repairs carried out in such areas that released these organic contaminants.
Phenol irritates skin and causes its necrosis, it damages kidneys, liver, muscle and eyes. Damage to skin is caused by its coagulation related to reaction to phenol with amino acids contained in keratin of epidermis and collagen in inner skin [32]. BTEX are important chemicals which occur naturally in crude oil and can be found in the vicinity of natural gas and petroleum deposits and also from gas emissions. Manmade releases of BTEX compounds in the environment are through motor vehicles, lubricating oil, losses during petrol marketing, gasoline, aircrafts and cigarette smoke [28]. They are used during the processing of petroleum products and during the production of consumer goods such as paints and lacquers, thinners, rubber products, adhesives. As can be seen in this study, BTEX compounds are present in ST5 (NNPC filling station near some automobile workshops) are as a result of excessive human activities such as dispensed of diesel, gasoline, lubricating oil e.tc. in the environs. Because of their polarity and very stable characteristics, BTEX compounds will be able to enter the soil, groundwater systems, taken up by plants and cause serious contamination problems. The acute exposure to BTEX has been associated with skin and sensory irritation, central nervous system problems and effects on the respiratory system [5]. [33], reported that 
leachate from waste disposal site of chemical works contained high concentration of BTEX and PAH in each case more than $75 \%$.

\section{Conclusion}

The increasing amount of total metals $(\mathrm{Fe}, \mathrm{Ni}$, $\mathrm{Cr}, \mathrm{Pb}$ and $\mathrm{Co}$ ), bioavailable contents and organic contaminants (Halo alkanes, phenolic and BTEX) in the soil could be due to human activities such as improper disposal of solid wastes, leaks from petroleum products, solvents, oils, petrochemicals, cigarette smoke, use of pesticides or disinfectants etc. The exchangeable fraction was the most abundant pool for most metals in the soil examined which could be possibly absorbed by plants. Significant amount of $\mathrm{Ni}$, $\mathrm{Cr}, \mathrm{Pb}$ and $\mathrm{Co}$ were associated with the non-residual fractions in the soils, which indicated that these metals were potentially bioavailable. These may pose a real threat as they are transferred into the food chain from soil contaminated by metals and organic contaminants, especially sample from ST3 which is an agricultural area.

\section{References}

[1] P.A. Aloysius, S.A. Rufus, O.O. John, Evaluation of heavy metals in soils around auto mechanic workshop cluster in Markurdi, Central Nigeria, Journal of Environmental Chemistry and Ecotoxicology, 5 (2013) $298-306$.

[2] S. McEldowney, Assessment and reclamation of contaminated land. Edited by Hester RE, Harrison RM, Royal Society of Chemistry, Cambridge, 2001, Journal of Chemical Technology and Biotechnology, 77 (2002) 1191 -1192. [DOI]

[3] J. Scullion, Remediating polluted soils, The Science of Nature, 93 (2006) 51-65. [DOI]

[4] T.C. Vanbrummelen, C.A.M Vangestel, R.A. Verweij, Long-term toxicity of five polycyclic aromatic hydrocarbons for the terrestrial isopods Oniscus asellus and Porcellio scaber, Environmental Toxicology and Chemistry, (1996) 1199-1210. [DOI]

[5] M. Srijata, R. Pranab, BTEX: A serious groundwater contaminant, Research Journal of Environmental Sciences, 5 (2011) 394-398. [DOI]

[6] M. Aliyu, M. Bello, Determination of heavy metal in Automobile workshop in Kaduna, Journal of FTS, 43 (2004) 2385-2398.

[7] K.H. Tan, Environmental soil sciences. Marcel Dekker, New York: Marcel Dekker, Hardbound, Geoderma, (2000) 425. [DOI]
[8] United States Environmental Protection Agency (1999), METHOD 3050B. Acid digestion of sludges, sediments and soil, "Revision 2. Washington, D.C.

[9] G. Rauret, J.F. López-Sanchez, A. Sahuquillo, E, Barahona, M. Lachica, A.M Ure, Application of a modified BCR sequential extraction (threestep) procedure for the determination of extractable trace metal contents in a sewage sludge amended soil reference material (CRM483), complemented by a three-year study of acetic acid and EDTA extractable metal content, Journal of Environmental Monitoring, 2 (2000) 228-233. [DOI]

[10] United States Environmental Protection Agency (2010). Method 1668C: Chlorinated Biphenyl Congeners in Water, Soil, sediment, biosolids, and tissue by HRGC/HRMS. Available at www.epa.gov/waterscience/methods

[11] M.L Vitosh, J.W Johnson, B. Mengel, (1995). Tri-State Fertilizer Recommendation for Corn, Soybean and Wheat, Extension bulletin E, New York.

[12] I. Alkorta, J. Hernandez-Alica, J.M Becerril, I. Amezaga, I. Albizu, C. Garbisu, Recent findings on the Phytoremediation of Soils Contaminated with Environmentally Toxic Heavy Metals and Metalloids such as Zinc, Cadmium, Lead and Arsenic, Reviews in Environmental Science and Bio/Technology, 3 (2004) 71-90. [DOI]

[13] T. Vamerali, M. Bandiera, G. Mosca, Field Crops for Phytoremediation of Metal Contaminated Land. A Review, Environmental Chemistry Letters, 8 (2010) 1-17. [DOI]

[14] J.K Pradhan, S. Kumar, Informal e-waste recycling: Environmental risk assessment of heavy metal contamination in Mandoli industrial area, Delhi, India, Environmental Science and Pollution Research, 21 (2014) 7913-7928. [DOI]

[15] B.Y. Fosu-Mensah, A. Emmanuel, Y.T Dzidzo, N. Frank, Heavy metals concentration and distribution in soils and vegetation at Korle Lagoon area in Accra, Ghana, Cogent Environmental Science. 3 (2017) 1405887. [DOI]

[16] WHO/FAO. (2001). Codex alimentarius commission. Food additives and contaminants. Joint FAO/WHO Food Standards Programme, ALINORM 10/12A. Retrieved from www.transpaktrading.com/static/pdf/research/ achemistry/introTofertilizers.pdf.

[17] K.A Yusuf, Sequential extraction of lead, copper, cadmium and zinc in soils near Ojota 
waste site, Journal of Agronomy, 6 (2) (2007) 331-33. [DOI]

[18] G. A. Oluwatson, O.D. Adeyolanu, T.O. Dauda, G.E. Akinbola, Levels and geochemical fractions of $\mathrm{Cd}, \mathrm{Pb}$ and $\mathrm{Zn}$ in valley bottom soils of some urban cities in South-Western Nigeria, African Journal of Biotechnology, 7 (2008) 3455-3465.

[19] S.I. Torri, R.S. Lavado, Dynamics of Cd, Cu and $\mathrm{Pb}$ added to soil through different kinds of sewage sludge, Journal of Waste Management, 28 (2008) 821-832. [DOl]

[20] W.L.O. Jimoh, Y. Sabo. Sequential Analysis of Metals in Municipal Dumpsite Composts of Kano Metropolis, Nigeria, Bayero Journal of Pure and Applied Sciences, 6 (2013) 87 - 91. [DOI]

[21] B.N. Hikon, G.S. Ngantem, G.O. Egah, D.D. Bwede, Assessment of Heavy Metals Contamination in Soils Impacted by Mining Activities in Akwana, Taraba State, Nigeria, Research Journal of Life Sciences, Bioinformatics, Pharmaceutical and Chemical Sciences, 4 (2018) 287-312. [DOl]

[22] M.O. Lisbeth, K.H. Henrik, E.J. Pernille, Relation Between $\mathrm{pH}$ and Desorption of $\mathrm{Cu}, \mathrm{Cr}$, $\mathrm{Zn}$, and $\mathrm{Pb}$ from Industrially Polluted Soils, Water, Air, \& Soil Pollution, 201 (2008) 295304. [DOI]

[23] A. Giacalone, A. Gianguzza, S. Orecchioa, D. Piazzesea, G. Dongarra, Metals distribution in the organic and inorganic fractions of soil: a case study on soils from Sicily, Chemical Speciation and Bioavailability,17 (2005) 83-93. [DOI]

[24] A.D.K. Banerjee, Heavy metals levels and solid phase speciation in street dust of Delhi, India, Environmental Pollution, 123 (2003) 95-105. [DOI]

[25] S. Tokalioglu, K. Senol, B. Gokhan, Application of Three Stages Sequential Extraction Procedure for the Determination of Extractable Metal Content in Highway Soils, Turkish Journal of Chemistry, 27, (2003) 333 - 346.

[26] I.A. Okoro, T. Abii, Chemical Speciation of Minerals and Toxic Metals In Sediments from a Local Stream (Anya Stream) Umudike, Ikwuano L.G.A in Abia State in Southeastern Nigeria, Continental Journal of Environmental Sciences, 5 (2011) 13 - 19.

[27] C. Osu, A. Asuoha, N. Adaku, Polycyclic Aromatic Hydrocarbons (PAHs) and Benzene, Toluene, Ethylbenzene, and Xylene (BTEX) Contamination of Soils in Automobile Mechanic Workshops in Port-Harcourt Metropolis, Rivers
State, Nigeria. Journal of American Science, 6 (2010) $244-246$.

[28] Agency for Toxic Substances and Diseases Registry (ATSDR) (2007). Toxicological profile for benzene. US Department of Health and Human Services. Retrieved from https://www.ehp.gld.gov.au>btex-report on $13^{\text {th }}$ August, 2018.

[29] Linda, Crampton (2017). Chloroform in the environment and its health dangers. Retrived from https://owlcation.com/stem/Chloroform-inthe-Environment-and-its-Dangers on 17th September, 2018.

[30] United States Environmental Protection Agency (2016). Risk evaluation for carbon tetrachloride. Retrieved from https://www.epa.gov/assessingand-managing-chemicals-under-tsca/riskevaluation-carbon-tetrachloride

[31] Agency for Toxic Substances and Diseases Registry (ATSDR) (2000). Toxicological profile for phenol (update). Public Health Services, U.S. Department of Health and Human services. Retrieved from https://www.epa.gov on 12th September, 2018.

[32] M. Iwata, Y. Eshima, H. Kagechika, H. Miyaura, The endocrine disruptors' nonylphenol and octylphenol exert direct effects on $\mathrm{T}$ cells to suppress $\mathrm{TH} 1$ development and enhance $\mathrm{TH} 2$ development, Immunology Letters, 94 (1-2) (2004) 135-139. [DOI]

[33] W. Jacek, M. Tadeusz, Determination of Volatile Organic Compounds (VOCs) in Water and Soil Using Solid Phase Microextraction, Chemia Analityczna, 47 (2003) 507-530.

\section{Acknowledgement}

The authors thank Mr. Godfrey G. S for his laboratory assistance.

\section{Funding}

No funding was received for conducting this study.

Is this article screened for similarity?

Yes

\section{Conflict of interest}

The authors have no conflicts of interest to declare that they are relevant to the content of this article.

About the License

(C) The author(s) 2021. The text of this article is open access and licensed under a Creative Commons Attribution 4.0 International License 